\title{
Adaptive Social Protection in Rwanda: 'Climate-proofing' the Vision 2020 Umurenge Programme
}

\author{
Paul B. Siegel, Justine Gatsinzi and Andrew Kettlewell*
}

\begin{abstract}
Rwanda has a high rate of rural poverty, population density and pressures on its natural resource base. One government response has been a social protection intervention, the Vision 2020 Umurenge Programme (VUP). VUP provides 'public works' employment for members of extremely poor households with able-bodied members, and 'direct support' cash transfers for poor households without members who can work. Many public works projects focus on environmental protection. VUP also promotes risk reduction activities related to food security and related health or nutrition issues. With increasing weather-related hazards and possibly climate change, administrators recognise the need to 'climate-proof' VUP in a manner that integrates social protection with disaster risk management, climate change adaptation and food security. This article highlights the potential for social protection policies and programmes in Ruanda to increase household and community resilience, by applying concepts of adaptive social protection and 'no regrets' approaches in a territorial context.
\end{abstract}

\section{Introduction}

Rwanda, the most densely populated country in sub-Saharan Africa, has a high rate of rural poverty and pressures on its natural resource base. Since the 1994 civil war and genocide, Rwanda has been on a positive development trajectory but remains a very poor country (about 60 per cent of the population lives below the poverty line and almost 40 per cent is classified as extremely poor). Vulnerability to periodic natural disasters, mainly droughts and floods, with linked problems to food insecurity and health epidemics, is a major concern (GoR 2009; WFP and NISR 2009; World Food Programme 2010).

This concern about multiple hazards linked to climate variability and extreme weather events provides Rwanda with an opportunity to better integrate social protection (SP) policies and programmes with disaster risk management (DRM), climate change adaptation (CGA), and food security (FS). The availability of geographic information systems (GIS), spatial data infrastructures (SDI), and information and communications technologies (ICT) have opened new possibilities for risk management (UNDP 2010; Siegel 2011).

This article ${ }^{1}$ describes Rwanda's flagship SP programme - Vision 2020 Umurenge Programme (VUP) - and offers recommendations on how to apply concepts and practices of adaptive SP and 'no regrets' approaches to better integrate SP with DRM, CCA and FS in order to 'climate-proof' VUP.

\section{Adaptive social protection and a 'no regrets' approach to climate-proofing SP, DRM, CGA and FS interventions are associated with different disciplines and communities of practice, operating in different institutions and using different conceptual frameworks and terminologies. Yet SP, DRM, CCA and FS all attempt to manage hazards or risks by transforming, strengthening and protecting assets and livelihoods, including efforts to improve institutional capacities, and to decrease vulnerability and build resilience, thereby promoting poverty-reducing sustainable growth. The concept of adaptive social protection (ASP) (Davies et al. 2009a,b) is a good starting}


point to consider integration of SP, DRM, CCA and FS. The assumption underlying ASP is that combining components of these different domains can improve the efficiency of interventions, lowering vulnerability and increasing resilience.

Although there has been limited explicit integration of SP/DRM/CCA/FS, there is some convergence or overlap in the realm of projects (World Bank 2009). For example, public works activities that are considered as SP or postdisaster infrastructure projects include interventions that are relevant for DRM/FS and/or CCA, such as land conservation and tree planting (World Bank 2010a).

The term resilience is increasingly used in the development community to indicate a proactive asset/livelihood approach to SP, DRM, CCA and FS that specifically targets poor and at-risk individuals, households and communities (Siegel 2011). We refer to this as a 'no regrets' approach because it aims to lower vulnerability against multiple hazards by transforming, strengthening and protecting assets and livelihoods, including the provision of basic needs. 'No regrets' actions are actions taken by households, communities and institutions that can be justified from economic, social or environmental perspectives, whether hazard events or climate change take place or not. The 'no regrets' approach is critical for poverty and vulnerability reduction in a world of multiple hazards (Heltberg et al. 2009; UNDP 2010; Siegel 2011). UNDP (2010) defines 'climate-proofing' as actions that make systems more resilient and resistant to hazards associated with climate variability and extremes, as well as geological hazards. Many climate-proofing activities are "no regrets' and promote ASP, and vice versa.

\section{Rwanda's Vision 2020 Umurenge Programme (VUP)}

Implemented since 2008, VUP is an SP programme, managed and implemented by Rwanda's Ministry of Local Government (MINALOC), with the goal of helping to reduce extreme poverty. By mid-2011, VUP was active in the four poorest sectors of all 30 districts (i.e. 120 sectors out of 416 sectors in Rwanda), and there are plans to expand coverage year-by-year. VUP aims to build, strengthen and protect household and community assets and livelihoods, and to increase productivity by providing transfers and access to finance plus technical assistance for family planning, hygiene and financial literacy, and public works to improve natural resource management and environmental quality. VUP beneficiaries are expected to 'graduate' from the programme over time on a sustainable basis.

Targeting of beneficiaries is done by classifying households using the community-based Ubudehe system. There are six household (HH) Ubudehe categories: $1=$ poorest, no able-bodied person(s); $2=$ very poor, with able-bodied person $(\mathrm{s}) ; 3=$ poor, some land and housing; $4=$ resourceful poor; $5=$ food rich; $6=$ money rich. Periodically, Ubudehe information for each sector is recorded as social maps, which are hand-drawn community maps that indicate where different types of households are located. Information about households drawn on social maps could be digitised on community maps used for the ongoing national land registration exercise. MINALOG recently conducted a national Ubudehe exercise to categorise households as part of a community-based management information system.

There are three types of VUP benefits: (a) 'direct support' payments to poorest households without able-bodied members; (b) 'public works' for poor households with an able-bodied member; (c) access to subsidised credit and other financial services. VUP public works projects are dominated by anti-erosive ditches and radical terracing of hillsides, which aim explicitly at environmental protection (Gatsinzi 2010). Such public works have clear DRM/FS and CCA impacts as they reduce exposure to natural disasters (e.g. droughts and floods), improve soil productivity and also expand the amount of cultivatable land. As such, public works can reduce vulnerability, build resilience and increase incomes and food security, in a virtuous cycle that links $\mathrm{SP}$ with DRM/FS and CCA. Multiple benefits from a similar programme have been documented for the Productive Safety Net Programme (PSNP) in Ethiopia (World Bank 2010c).

Classification of potential VUP beneficiaries is conducted annually, and benefit packages are set based on local conditions (e.g. wage rates for public works are based on prevailing wages). Contracts for public works are negotiated on a project-by-project basis, with cash transfers set 
at or near local market wage rates. Payments for public works are made after each two-week work cycle. Direct support cash transfers are based on a national scale of monthly amounts paid for a year, with payments made (to bank accounts of beneficiaries) approximately every month. The amount paid reflects the number of household members on a reducing scale up to a maximum of five household members. Financial terms for micro-loans, including interest rates and repayment schedules, are agreed upon at time of processing the loan. The concept of receiving money from government that needs to be repaid is a new concept for poor rural households, and so far the incentives to default are high.

Beneficiaries also qualify for benefits from other social programmes, and VUP helps them access these other programmes. These are examples of efforts by VUP to provide a range of vulnerability-reducing and resilience-increasing activities (e.g. family planning, hygiene, nutrition and improved cooking technology, business and financial literacy) to beneficiaries. These 'no regrets' vulnerability-reducing, resilience-building interventions are also examples of the overlaps between SP, DRM, CGA and FS (Heltberg et al. 2009, 2010; Siegel and de la Fuente 2010; UNDP 2010; Siegel 2011).

\section{Need for 'climate-proofing' VUP}

VUP administrators recognise the need to deal with increased frequency and severity of natural hazards (e.g. droughts and floods) and related hazards (e.g. illness, malnutrition, high food prices). Thus, there is interest in 'climateproofing' the VUP by explicitly integrating SP with DRM, GCA and FS. Such an approach requires community-based early warning systems (EWS) that can trigger rapid responses, with the VUP being flexible enough (with appropriate institutional and financial capacity) to update its targeted beneficiary list and benefits and public works activities and benefits based on changing economic, social and environmental conditions.

Identification of VUP beneficiaries is carried out annually, but VUP and non-VUP households are vulnerable to various hazards during a year, which manifest themselves through food insecurity, malnutrition, diseases, lack of water, unemployment, crop failure, livestock losses, loan defaults, etc. Such hazards can force VUP households to adopt unplanned coping strategies that can harm assets and livelihoods, and even cancel benefits of the project (e.g. households can 'fall back', by moving from category 2 to 1 , or from category 3 to 2 ).

There is a need for objective and transparent early warning 'triggers' to facilitate rapid response, and flexibility in the targeting of beneficiaries and benefit packages (e.g. the ability to scale-up direct support or mobilise 'offthe-shelf' public works projects). Ethiopia's PSNP recognised the need to provide early warning and rapid response mechanisms with a well-defined institutional structure that links levels of decision-making and governance from the community to district to national levels across ministries and in cooperation with donors and NGOs (IDL Group 2009; World Bank 2010c). The PSNP has recently created a 'Risk Financing Component' that integrates early warning systems with preparedness and contingency plans and contingency financing in a manner that is community-based and linked to district and national levels for implementation.

\section{National Social Protection Strategy (NSPS)}

Rwanda's NSPS was approved in early 2011, and an implementation plan which seeks to harmonise and formalise existing SP policies and programmes is being prepared. Ministries responsible for the NSPS include Local Government (MINALOG), Health (MINISANTE) and Education (MINEDUG). VUP is an important part of the NSPS (GoR 2011), which includes a section on risk management that highlights the need to integrate SP with CGA, DRM and FS and to initiate early warning and rapid response systems, including contingency plans and financing.

Risk management approaches of the NSPS and VUP draw upon experiences in other countries, especially the Ethiopia PSNP (IDL Group 2009; Wiseman and Hess 2008; World Bank 2010c), and the Kenya Arid Lands Resource Development Project (GEF 2007), notably the focus on a community-based and nationally coordinated system (via districts) for DRM/CCA/FS. There are also similarities with the Kenya Hunger Safety Net Programme (HSNP).

For fiscal year 2011-12, VUP has requested budget to: (a) establish a 'Risk Management Fund', which will make additional funds available 
for VUP sectors that face major hazards; and (b) provide sector-level budgets for direct support and public works that are based on poverty and vulnerability profiles of the respective sectors. The fund is only 2 per cent of the VUP budget, but it allows the risk management scheme to be piloted.

\section{6 'Climate-proofing' VUP: recommendations}

To 'climate-proof' the VUP (where 'climate proofing' is viewed as an entry-point to a multihazard approach to risk management) requires coordination among VUP/MINALOC and other stakeholders. A guiding principal for ASP and the 'no regrets' approach is 'do not reinvent the wheel'. This means there is a need to adapt and link existing institutions and programmes to the extent possible. The role of MINALOG is critical because it offers a combination of national coverage and strong local government and community presence, which can help coordinate early warning and preparedness systems to anticipate the impacts of climate hazards, and mobilise a post-hazard event response. Below are some specific recommendations for 'climateproofing' the VUP.

\section{Improve national, district, watershed level} systems for climate data, forecasting and early warning. A major link between SP, DRM, CCA and FS is through weather and climate information and early warning and rapid response systems (UNDP 2010; Siegel 2011). Good weather and climate information is the foundation of any attempts to deal with climate variability and change, and extreme weather events. Improved hydro-meteorological stations are critical for collecting, analysing and disseminating information in a timely manner. There is an urgent need to expand the number of well-functioning weather stations in the national Meteo system, and strengthen the organisational structure and capacity of the Meteo to provide better baseline, forecasting and early warning weather/climate information. The implementation plan for the new Meteo Strategy (GoR 2010) should have broad stakeholder participation and consultation that includes VUP/MINALOC, who are potential users and providers of weather and climate information.

The USAID-financed Famine Early Warning Network (FEWSNet) is (re)opening an office in Rwanda in 2011. FEWSNet is designed to provide early warning of climate and climate-related hazards, food insecurity, vulnerability to food insecurity and famine. FEWSNet utilises satellite-based remote-sensing and ground-based surveys, and builds national capacity in early warning and food security monitoring and assessment capabilities. It is critical for GoR to ensure that FEWSNet is appropriately integrated into the Rwandan Meteo and early warning and rapid response systems.

In 2010 the International Finance Corporation approved a grant of $\$ 1.6$ million to MINAGRI and MicroEnsure Inc. to pilot weather-index insurance in six districts using manually operated rain gauges. The plan is to pilot the weatherindex ('rainfall') insurance by reaching farmers through financial institutions and input suppliers. This initiative is an important awareness-building exercise for various stakeholders in Rwanda. However, there is a lack of 'best practices' experiences in the world that use manual rain gauges for commercially oriented weather-index insurance (Hellmuth et al. 2009). Use of automated and secure weather stations is critical for successful implementation of this pilot and for future scaling-up, and these stations should be part of the national Meteo system.

\section{Expand national, district, watershed level} planning and use of geographic information systems (GIS), spatial data infrastructure (SDI) and information and communication technology (ICT). Rwanda has made considerable progress with mapping and GIS, and is beginning to establish SDI using different ICT to help manage the data. Since 2008, the National Land Commission (NLC) has made a major effort to create a National Land Registry with private land titles (Nkurunziza 2010). There are aerial photos of almost all of Rwanda with low-altitude digital photography that can be used to produce community-level maps. The NLG has also generated a national Land Use Plan (LUP) including maps that identify 'high-risk' areas for floods and droughts, and areas not suitable for agriculture. Data for the national LUP will be used to generate district-level LUPs, and they have many uses for territorial planning, based on adaptive SP.
Improve coordination and integration of meteorological data, EWS, GIS, SDI and ICT for climate resilience: technical and policy perspectives that link SP/DRM/CCA/FS. There is 
an urgent need for greater coordination and integration of meteorological data, EWS information, GIS, SDI and associated ICT to improve the integration of planning for SP, DRM, CCA and FS under the overall 'umbrella' of climate-proofing and building resilience. This needs to be done in and by Rwanda; however it is also possible to draw upon a wide range of SP expertise in Africa and elsewhere (Devereux and Cipryk 2009; Siegel 2011). Strategies and implementation plans related to SP, CCA, DRM and FS must be harmonised, especially with respect to overlaps in information and data collection, analysis and dissemination. The new NSPS proposes a multi-sectoral Technical Working Group that focuses on 'Meteorological Data, GIS, EWS and ICT for Climate Resilience'.

\section{Upgrade community-based early warning and} rapid response systems. The key to a multihazard rapid response system is having community-based EWS in place, which, in turn, requires a system of real-time community-based planning/monitoring/evaluation (World Bank 2009; UNDP 2010; Siegel 2011). Since the VUP has a strong community presence, this is a good starting point for district- and national-level early warning and rapid response systems. The community-based EWS should be linked to ongoing analytical work (e.g. the current Household Census carried out by the National Institute of Statistics Rwanda) to identify vulnerable households and communities.

VUP needs a community-based EWS that can trigger rapid responses, with the VUP being flexible enough to update its targeted beneficiaries and benefits and public works activities based on changing economic, social and environmental conditions. As a starting point, there is a need to combine low-tech and hightech approaches. The Ministry of Health (MINISANTE) has made significant progress using community-based health monitors and cellphones to transmit data to other levels. They have ongoing monitoring and emergency alerts, and a monthly survey form, with a focus on health status of vulnerable individuals and households, and 'early warning' if there are problems for individuals or households, where information is transmitted by cell-phones.

A simple idea for a community-based EWS is that communities compile a 'scorecard' with about 20 variables that reflect nutrition, health, status of crops and livestock, food /feed in storage, market prices of key consumption items, environmental indicators and climate data, with 1-5 scale for each indicator that can be added up to create a 'community vulnerability index'. This information would generate 'triggers' that signal the need for a rapid response, such as the information generated by weather-index insurance. The scorecards could provide valuable information for the present and future, and also provide a historical record for ongoing analyses. VUP staff, health monitors or NGOs can conduct participatory exercises with community to score the different indicators.

It is important to provide support for coordinated, consolidated and streamlined community-based monitoring systems to build a 'bottom-up' system to complement and strengthen the more 'top-down' FEWSNet and meteorological service weather and hydrology forecasts. This entails creating a system of clear and easy-to-measure indicators that can be monitored to generate an objective and transparent set of early warning 'triggers' and have a menu of rapid responses that are well targeted and protect assets and livelihoods, and build more resilient assets and livelihoods. The Ethiopia PSNP uses community-based means testing to identify potential SP programme beneficiaries and remote sensing technology and GIS to support early warning and rapid response systems, with a contingency fund to finance resilience-building public works (Wiseman and Hess 2008; Hellmuth et al. 2009).

Facilitate activities that reduce vulnerability and increase resilience. A key aspect of SP is reducing vulnerability and increasing resilience through improved management of household/community assets and livelihoods. Attention must be focused on management of short-term climate variability and extreme weather events, and directly/ indirectly related hazards. Managing the seasonality of food, labour and cash flows are all critical determinants of wellbeing for poor and near-poor households. However, there is much that communities and households can do for themselves - and mobilising community resources is an important aspect of the design of VUP. As such, VUP is sensitising beneficiaries about available social services, including access to family planning, improved cooking and nutrition, 
sanitation and hygiene practices, housing and food storage, financial literacy and training for small businesses.

Gatsinzi (2010) notes that many public works projects associated with VUP are focused on improving land-use management (e.g. terracing, reforestation, water harvesting and management). Thus, there are inherent links to DRM, CGA and FS. To ensure that VUP public works are environmentally friendly and beneficial, Rwanda Environmental Management Agency (REMA) has placed a technical specialist in VUP to help with environmental assessments of VUP-funded public works projects. For an effective early warning and rapid response system, it is important that there are 'off-theshelf' public works projects that can be scaled-up and down in response to hazard events.

Improve systems for transfer payments and access to finance/insurance services. The VUP deposits payments for direct support and public works directly into accounts that beneficiaries are required to open at a local bank or microfinance institution. Since VUP beneficiaries have their own bank accounts, they can benefit from a range of finance and insurance services, including savings (which are voluntary but highly encouraged) and access to subsidised credit. Savings are used for basic consumption needs, health insurance, school fees and investments in small livestock and are also a form of 'selfinsurance' against negative impacts of different hazards. VUP offers 'finance literacy' training for its beneficiaries, as another 'no regrets' approach to greater resilience by strengthening human, social and financial assets.

\section{Notes}

* The views expressed in this article are the views of the authors and do not necessarily reflect the views or policies of the World Bank, its Board of Governors or the governments they represent. The views also do not represent those of the Government of Rwanda.
In terms of financial services, the first priority for VUP is to improve the timeliness and predictability of cash transfers (Devereux and Ndejuru 2010). Second priority is to improve access to savings accounts and withdrawals. The third priority is to improve credit and insurance offerings - there are several innovative finance and insurance products for poor households (see Hoddinott 2009; World Bank 2010b). VUP could also examine the possibility of offering weatherindex insurance to beneficiaries. VUP could even purchase weather-index contracts in high-risk areas, then allocate indemnity payments to beneficiaries.

\section{Conclusion}

Rwanda faces many challenges, but these challenges also provide opportunities. 'Climateproofing' the VUP is a major endeavour, but this is needed to protect the investments made in supporting the poorest and most vulnerable households, as part of a national poverty reduction strategy. There is a need to integrate policies and programmes related to SP, DRM, CCA and FS. This will require greater cooperation between government ministries and agencies, donors and NGOs, including the sharing of weather and climate information and information about households and the local economic, social and environmental conditions to inform early warning and rapid response systems. This necessitates a well-articulated and coordinated approach to policies and programmes related to ASP, and flexible 'no regrets' approaches to increasing household and community resilience within territories.

1 See Siegel et al. (2011) for a more detailed version of this article. Also see Siegel (2011); Siegel and de la Fuente (2010); Heltberg et al. (2009, 2010) and UNDP (2010) for more on SP, DRM/CGA and 'no regrets' approaches. 


\section{References}

Davies, M.; Guenther, B.; Leavy, J.; Mitchell, T. and Tanner, T. (2009a) Climate Change Adaptation, Disaster Risk Reduction and Social Protection: Complementary Roles in Agriculture and Rural Growth?, IDS Working Paper 320, Brighton: IDS

Davies, M.; Oswald, K. and Mitchell, T. (2009b) 'Climate Change Adaptation, Disaster Risk Reduction and Social Protection', in Promoting Pro-Poor Growth: Social Protection, DAC Network on Poverty Reduction (POVNET), www.oecd.org/document/31/0,3343,en_2649 34621_41169119_1_1_1_1,00.htm (accessed 4 August 2011)

Devereux, S. and Cipryk, R. (2009) Social Protection in Sub-Saharan Africa: A Regional Review, Brighton: Centre for Social Protection, IDS

Devereux, S. and Ndejuru, A. (2010) Annual Review of DFID Support to the Vision 2020 Umurenge Programme (VUP), Rwanda, report prepared for the UK's Department for International Development (DFID), Brighton: IDS

Gatsinzi, J. (2010) 'Environmentally Friendly Public Works: Experiences from the VUP in Rwanda', presentation at World Bank Retreat for Social Protection in Africa, Dar-es-Salaam, Tanzania

GEF (Global Environment Fund) (2007) Kenya Adaptation to Climate Change in Arid Lands (KACCAL), Washington DC: World Bank, www.thegef.org/gef/sites/thegef.org/files/ documents/document/08-10-09-SCCF.pdf (accessed 4 August 2011)

GoR (Government of Rwanda) (2011) National Social Protection Strategy, Kigali: Ministry of Local Government

GoR (Government of Rwanda) (2010) Rwanda Meteorological Service: Strategic Plan 2010-2015, Kigali: Ministry of Infrastructure

GoR (Government of Rwanda) (2009) State of Environment and Outlook, 2009, Kigali: Rwanda Environmental Management Agency (REMA), www.rema.gov.rw/soe/ (accessed 8 August 2011)

Hellmuth, M.E.; Osgood, D.E.; Hess, U.; Moorhead, A. and Bhojwani, H. (eds) (2009) 'Index Insurance and Climate Risk: Prospects for Development and Disaster Management', Climate and Society 2, New York: International Research Institute for Climate and Society, Columbia University

Heltberg, R.; Siegel, P.B. and Jorgensen, S.L. (2010) 'Social Policies for Adaptation to Climate Change', in R. Mearns and A. Norton (eds), Social Dimensions of Climate Change: Equity and Vulnerability in a Warming World, Washington DC: World Bank

Heltberg, R.; Siegel, P.B. and Jorgensen, S.L. (2009) 'Addressing Human Vulnerability to Climate Change: Toward a "No Regrets" Approach', Global Environmental Change 19.1: 89-99

Hoddinott, J. (2009) 'Social Protection and Risk: Innovations in Insuring the Poor', Focus 2020:

Focus 17, Brief 14, Washington DC: International Food and Policy Research Institute (IFPRI), www.ifpri.org/sites/default/files/publications/ focus 17 14.pdf (accessed 8 August 2011)

IDL Group (2009) Ethiopia Productive Safety Net Programme (PSNP): Design of a Risk Financing Mechanism, Product 4: Final Guidelines for the PSNP Risk Financing Mechanism in Ethiopia, Bristol: IDL Group

Nkurunziza, E. (2010) 'Low Cost Titling in Africa: Land Tenure Regularization in Rwanda', Rwanda National Land Centre, presentation to the World Bank Annual Land Conference, Washington DC, 26-27 April, http://siteresources.worldbank.org/EXTARD/ Resources/336681-1236436879081/5893311$1271205116054 /$ nkurunziza.pdf (accessed 4 August 2011)

Siegel, P.B. (2011) “"No Regrets” Approach to Decision-Making in a Changing Climate: Toward Adaptive Social Protection and Spatially Enabled Governance', background paper prepared for World Resources Institute for the 2010 World Resources Report on DecisionMaking for Climate Change, www.worldresourcesreport.org/responses/noregrets-approach-decision-making-changingclimate-toward-adaptive-social-protection-a (accessed 4 August 2011)

Siegel, P.B. and de la Fuente, A. (2010) 'Mainstreaming Natural Disaster Risk Management into Social Protection Policies (and vice versa) in Latin America and the Caribbean', Well-Being and Social Policy 6.1: 141-73

Siegel, P.B.; Gatsinzi, J. and Kettlewell, A. (2011) 'Adaptive Social Protection in Rwanda: A No Regrets Approach to Increased Resilience in Territorial Planning Context', paper presented at a conference on Social Protection for Social Justice, Brighton: Centre for Social Protection, IDS, http://ids.ac.uk/go/researchteams/vulnerability-and-poverty-reductionteam/centre-for-social-protection/csp- 
conference-2011/csp-conference-papers (accessed 4 August 2011)

UNDP (United Nations Development Programme) (2010) A 'No-Regrets'Risk-Based Approach to Climate-Proofing of Public Infrastructure: Improved National and Sub-National Planning for Resilience and Sustainable Growth, www.adaptationlearning.net (accessed 8 August 2011)

Wiseman, W. and Hess, U. (2008) 'Incorporating Weather Indices into Early Warning Systems for Emergency Response and Social Protection: The Case of Ethiopia', presentation made at the World Bank, Washington DC

World Bank (2010a) 'Incorporating Social Dimensions in the Infrastructure Recovery and Assets (INFRA) Platform', INFRA Guidance Notes, IN-4, http://web.worldbank.org/ WBSITE/EXTERNAL/TOPICS/EXTSDNET/ 0,,contentMDK:22493665 menuPK:6395187 pagePK:64885161 piPK:64884432 theSite PK:5929282,00.html (accessed 4 August 2011) World Bank (2010b) World Bank Group: Financial Solutions for Catastrophic Risk Management, Washington DC: World Bank, http://treasury. worldbank.org/bdm/pdf/Brochures/Catastrophe _Risk_Financing_Brochure.pdf (accessed $\overline{4}$ August 2011)
World Bank (2010c) Designing and Implementing a Rural Safety Net in a Low Income Setting: Lessons Learned from Ethiopia's Productive Safety Net Program 2005-2009, Washington DC: World Bank, http://siteresources.worldbank.org/ SafetyNetsAndTransfers/Resources/Ethiopia PSNPLessonsLearnedLite.pdf (accessed 4 August 2011)

World Bank (2009) Building Resilient Communities: Risk Management and Response to Natural Disasters through Social Funds and Community-Driven Development Operations, Washington DC, http://siteresources.worldbank.org/INTSF/ Resources/Building_Resilient_Communities_ Complete.pdf (accessed 4 August 2011)

World Food Programme (2010) Consultation on the Identification of Food Security and Nutrition Interventions, Response Analysis Project, http://home.wfp.org/stellent/groups/public/ documents/ena/wfp218821.pdf (accessed 4 August 2011)

WFP and NISR (World Food Programme and National Institute of Statistics Rwanda) (2009) Rwanda Comprehensive Food Security and Vulnerability Analysis and Nutrition Survey, http://amis.minagri.gov.rw/content/rwandacomprehensive-food-security-and-vulnerabilityanalysiscfsva (accessed 4 August 2011) 